\title{
CAREER ADVANCEMENT AMONG WORKERS IN PUBLIC AND PRIVATE ORGANISATIONS IN SOUTHWEST NIGERIA
}

\author{
Babatunde Joshua Omotosho
}

\begin{abstract}
Recent studies have argued that workers no longer enjoy upward mobility in their careers due to a number of challenges. However, little is understood regarding some of the factors responsible for this development. This study examined career advancement among workers in private and public organisations in southwest Nigeria. A total of ninety-six questionnaires were distributed among the same number of respondents at selected public and private organisations in Ado Ekiti. The study also used in-depth interviews to elicit qualitative information from a total of twelve adult male and female respondents. Results indicate that respondents feel they have not enjoyed the desired career advancement at their workplaces.
\end{abstract}

KEYWORDS: Career, Promotion, Workplace, Organisation, Gender, Occupational mobility

\section{INTRODUCTION AND PROBLEM STATEMENT}

The importance of career development cannot be understated; most workers at most organisations desire to be upwardly mobile in their chosen professions. While it may appear that the benefits of such mobility are only enjoyed by workers, studies have shown that the government, individuals and employees all have a stake and thus all benefit when these three areas function together effectively (Foster - Purvis 2011). For organisations, the career advancement of workers is one viable method for attracting and retaining the best employees; the success of

1 Babatunde Joshua Omotosho, Department of Sociology, Faculty of the Social Sciences, Federal University Oye-Ekiti, Nigeria, e-mail: babatundeomotosho@gmail.com 
workers due to career advancement is equally the success of the organisations. Aside from this, promotion gives employees a clear sense of direction and purpose, as well as ensures that the necessary skills are imparted to workers. Purcell, Kinnie, Hutchinson, Rayton, and Swart (2003) observed that supporting career advancement is one of the key practices for encouraging organisational accomplishment. For individuals, careers have a "subjective component: the sense that people make of their own career, their personal histories, and the skills, attitudes and beliefs that they have acquired" (Arthur 1994). Apart from providing social and psychological satisfaction, career development involves a learning process: within any given organisation, advancement and learning are indivisibly linked (Schein 1978; Hall 1976). By implication, when opportunities for career advancement are lacking, all the above benefits are diminished or completely absent, and discouragement may set in for workers; this in itself becomes a problem for organisations because it threatens productivity, and in the long run constitutes a serious challenge to policy makers.

One of the challenges that has bedevilled workplaces in recent times is the lack of desired career advancement (Foster - Purvis 2011). Workers may put in years of training, hard work, and commitment to an organisation, without commensurate upward career mobility. For instance, studies argue that when employees are laid off at minimal notice, those fortunate enough not to be sent packing do not enjoy any form of career progression (Foster - Purvis 2011). While there is a dearth of data that explains the advancement of workers along their career paths, the little that is available suggests that demotion rather than promotion is the experience of many workers. The findings of a study conducted by Dickens (2000) revealed that low-income employees are more likely to retrogress than progress in terms of career and income (Dickens 2000). The implication is that, as the income gap continues to increase, income mobility decreases (Dickens 2000; Stewart - Swaffield 1999). A number of factors have been employed to explain this phenomenon. Brüderl and his colleagues (1991) and Spilerman and Peterson (1998) attribute the career retrogression to organizational structures and personnel rules at workplaces, which in most instances are not negotiable. Brüderl et al. (1991) further cited a number of factors inhibiting promotion to include personal characteristics and gender. For instance, it is claimed that women are marginalised when it comes to promotion within the work environment. Factors ranging from chauvinism and sexual harassment (Zippel 2000); structuring the workplace in favour of men (Dickens, 2000); culture (Hartman 1979; Bryd-Blake 2004); and the glass-ceiling effect (Savage 2002) - among others - have been said to hinder women from climbing the career ladder. This indicates that a number of factors influence the career im/ mobility of workers within a given organisation. 
While abundant research efforts have been designed to explore the dynamics of occupational mobility within developed economies, relatively little is known about career development within the work place in developing economies. As a matter of fact, Kellard and Mitchel (2006) argue that information about progression within the workplace is entirely lacking. The presently described explorative study was designed to aid understanding of how workers perceive their career advancement within work places. For this purpose, a comparative study of opinions from within private and public organisations was conducted. Attention was paid to the fact that focussing on entry-level employment and labour market conditions (and so on) may not provide a clear understanding of the dynamics of career mobility within the workplace; a public-private investigation of how women fare was thus considered to be critical (Reinhart - Rogoff 2008; Verick 2009; Cahuc - Carcillo 2011; Bell - Blanchflower 2011; Schroeder et al. 2008). Aside from this, a number of phenomenon are identifiable in developing economies in the twenty-first century such as economic challenges, growth, and the uptake of information technology, along with less of a sense of commitment on the part of employers to their employees (and vice versa), increasing pressure on the work place (Tsui et al. 1997). Some studies have connected economic challenges with declining career mobility (Büttner et al. 2010; Barone et al. 2011). A 'survival of the fittest' approach appears to be gradually becoming the norm, and in the words of Valcour and Tolbert (2003), investigation of the career paths of the genders demands careful exploration. The authors of the present study therefore set themselves the task of investigating how workers perceive career advancement within the work environment. The research questions for the study are the following:

\section{Research Questions}

1. What are the perceived patterns of career advancement in selected organisations?

2. What are the determinants (as perceived by the respondents) of career advancement, and does disparity exist in the process, and, if so, what is (are) the cause(s)?

3. What are the perceptions of selected respondents about occupational mobility in selected organisations?

4. Do respondents perceive any hindrances to career advancement in the selected organisations?

Based on the research questions, the following study objectives were defined: 


\section{Objectives of the study}

The general objective of the study was to examine the perceptions of workers about career advancement in selected public and private organisations in southwest Nigeria. Within the selected organisations the specific objectives were to:

1. Understand the perceptions of respondents about career advancement.

2. Examine the trends of career advancement for male and female respondents.

3. Explore the factors that enhance advancement.

4. Assess the perceived constraints to advancement.

\section{BRIEF LITERATURE REVIEW}

Over the years, the belief has largely been that individuals within the workplace undergo unhindered career progression; that workers never change jobs, and that promotion, good pay and job satisfaction dominate almost all career paths (Valcour - Tolbert 2003). These kinds of beliefs are gradually declining in the modern era as evidence suggests that employment insecurity, a decline in organisational tenure, and difficulty in climbing the ladder of career development are gradually becoming common. Further, employers are no longer committed to employees, and the loyalty of employees is equally declining (Tsui et al. 1997). What is also interesting is that the gender composition of the work environment has changed considerably, such that there has been an increase in the number of women in the work force (Blau et al. 2002). These issues have together placed considerable pressure on organisations, meaning that they are no longer able to give their best to their workers.

The above situation supports the need for better understanding the factors that determine mobility within workplace, and the dimensions and impact of gender within the work environment as well. In explaining what a career connotes, Arthur, Hall and Lawrence (1989) and Blair-Loy (1999) refer to it as an arrangement of a person's work history and practices. To understand these past references and experiences, one of the factors that should be taken into consideration is how individuals move along the mobility ladder (up or down) within and across organisations (Valcour-Tolbert 2003). Schroeder et al. (2008) argued that while it is important to make such distinctions regarding career mobility, it is equally important to investigate whether groups or individuals are disadvantaged in the process of mobility, and whether the prospects are there for certain types of respondents in terms of making available to them the experiences and expertise that foster mobility (Schroeder et al. 2008). 
It is clear from the foregoing material that more empirical evidence about how workers move along the career ladder is needed; especially in developing countries with hitherto insufficient data for explaining these dynamics. This study intends to fill this gap by adding to the existing body of knowledge about how social and cultural factors within and outside the work environment influence the career paths of workers in both private and public establishments in Nigeria.

\section{RESEARCH METHODS AND PRESENTATION OF RESULTS}

The study was conducted in Ado Ekiti, in southwestern Nigeria. Being a relatively new state, quite a number of corporate bodies from within and outside the country have found their way to the state capital. The focus of the study was to increase understanding of the perceptions of workers about career advancement within public and private organizations, and it was easy to systematically select such organizations within the city for research. Two types of organizations were purposively selected for this study: public services owned by the state, and banking institutions owned by private individuals and bodies. The reason for selecting these two types was the fact that they have well-structured administrative systems, and they offer relatively high average salaries compared to other organizations within the state, meaning that employees desire to work at these institutions. From the two types of organizations, individuals were selected from one ministry (department) and two banks. Due to its large size of the ministry, a simple random procedure was adopted to select 43 respondents, while all the respondents in the professional and administrative cadres in the private establishments were selected for interviewing, totaling 53 respondents. A total of 96 respondents were thus included in this study. For the qualitative data, the study used in-depth interviews to elicit information from a total of 12 adult males and females within work settings (six males and six females). Quantitative data was analyzed using SPSS software. Frequency distribution tables were plotted to analyze all the issues. Several variables were also cross-tabulated to understand the relationships between them. The hypotheses formulated for the study were also tested using chi square statistical methods. As regards the in-depth interviews (IDI), these were analyzed individually and quotes are included verbatim, where necessary, to support findings from quantitative data. 
Table 1: Gender, Age and Marital Status in selected Public and Private Organisations (Frequency of Responses of Respondents) (\%)

\begin{tabular}{|c|c|c|c|c|c|c|}
\hline \multirow[b]{3}{*}{ Gender } & \multicolumn{4}{|c|}{ ORGANISATIONS } & \multirow[b]{3}{*}{ Frequency } & \multirow[b]{3}{*}{$\%$} \\
\hline & \multicolumn{2}{|c|}{ Public } & \multicolumn{2}{|c|}{ Private } & & \\
\hline & Frequency & $\%$ & Frequency & $\%$ & & \\
\hline Male & 28 & 65.1 & 27 & 50.9 & 55 & 57.3 \\
\hline female & 15 & 34.1 & 26 & 49.9 & 41 & 42.7 \\
\hline Total & 43 & 100.0 & 53 & 100.0 & 96 & 100.0 \\
\hline Age & Frequency & $\%$ & Frequency & $\%$ & Frequency & $\%$ \\
\hline $21-25$ & 7 & 16.3 & 8 & 15.1 & 15 & 15.6 \\
\hline $26-30$ & 4 & 9.3 & 35 & 66.0 & 39 & 40.6 \\
\hline $31-35$ & 8 & 18.6 & 8 & 15.1 & 16 & 16.7 \\
\hline $36-40$ & 5 & 11.6 & 2 & 3.8 & 7 & 7.3 \\
\hline $41-45$ & 9 & 20.9 & & & 9 & 9.4 \\
\hline $46-50$ & 4 & 9.3 & & & 4 & 4.2 \\
\hline $51+$ & 6 & 14.0 & & & 6 & 6.3 \\
\hline Total & 43 & 100.0 & 53 & 100.0 & 96 & 100.0 \\
\hline Marital Status & Frequency & $\%$ & Frequency & $\%$ & Frequency & $\%$ \\
\hline Single & 12 & 27.9 & 38 & 71.7 & 50 & 52.1 \\
\hline Married & 30 & 69.8 & 15 & 28.3 & 46 & 46.9 \\
\hline Separated & 1 & 2.3 & & & & 1.0 \\
\hline Total & 43 & 100.0 & 53 & 100.0 & 96 & 100.0 \\
\hline $\begin{array}{c}\text { Educational } \\
\text { Qualification }\end{array}$ & Frequency & $\%$ & Frequency & $\%$ & Frequency & $\%$ \\
\hline Diploma & 13 & 30.2 & 16 & 30.2 & 29 & 30.2 \\
\hline HND & 5 & 11.6 & 11 & 20.8 & 16 & 16.7 \\
\hline B.Sc. & 14 & 32.6 & 19 & 35.8 & 33 & 34.4 \\
\hline M.Sc. & 6 & 14.0 & 1 & 1.9 & 7 & 7.3 \\
\hline $\begin{array}{l}\text { B.Sc.+ Other } \\
\text { Certificates }\end{array}$ & 3 & 7.0 & 5 & 9.4 & 8 & 8.3 \\
\hline Others & 2 & 4.6 & 1 & 1.9 & 3 & 3.1 \\
\hline Total & 43 & 100.0 & 53 & 100.0 & 96 & 100.0 \\
\hline
\end{tabular}

The table above presents socio-economic and demographic characteristics about the respondents. As regards the gender composition of the study, a total of 41 females and 55 males participated in the study ( 42.7 percent and 57.3 percent, respectively). From the public organisation, 28 males (65.1 percent) and 15 females (34.1 percent) were represented in the study, while 27 males (50.9 percent) and 26 females (49.9 percent) participated in the study from private organisations. During the sampling procedure it was observed that there were more males workers in the public organisations than the private 
ones. IDI clarified that the services of women were more needed in the banking sector (private) than those of their male counterparts. However, no explanation could be given for the male-female population ratio within the public sector. Findings about age showed that the majority of the respondents could be classified into the 21-45 age cohort for the public service, and 26-30 for the private (66.0 percent of the total). However, no respondents of age 41 or above were found in the banking profession. Findings from IDI revealed that the work force is usually concentrated within those age brackets because working in the banking profession is demanding. As regards marital status, 69.8 percent and 28.3 percent of the samples from the public and private organisations were married, respectively, while 27.9 percent and 71.7 percent (respectively) were single.

Findings about educational qualifications should not be thought unusual considering the strong educational pursuits of Nigerians at all levels, while Ekiti, the study area, is also noted for its strong drive to promote education. Within the city of Ado Ekiti alone, there are over four tertiary institutions, with another two tertiary institutions within the towns adjoining the city. This, of course, may make it easy for interested workers to acquire further education qualifications. Further, a number of institutions in the country also run distancelearning courses which may make it easier to attain higher-level educational qualifications.

The table above illustrates the percentage distribution of respondents according to their perceptions about the promotional exercise and procedures for employees in selected public and private organizations in Ado Ekiti. Respondents that joined their workplaces before 1990 in both public and private accounted for 9.3 percent and 5.7 percent, respectively; those that joined between 1991 and 20009.3 percent and 1.9 percent in both public and private organizations; those that joined public and private establishments between 2001 and 2010 in constituted 20.9 percent and 5.7 percent, respectively, while those that joined from year 2010 until the survey date in both public and private establishments constituted 60.5 percent and 86.8 percent (resp.). The majority of the labour force within both organisations joined their place of employment at some point after 2001. Respondents were asked whether promotion was a regular phenomenon at their work place; a majority of respondents of public organizations affirmed this, as did 42.7 percent of respondents from private establishments. The remaining respondents ( 32.6 percent and 57.3 percent) in both public and private organizations (respectively) were asked to state why this was not so. In response, 85.7 (85.5) percent from public and private establishments (resp.) responded that it depends on the positions available within their units. 
Table 2: Perceptions about Procedures and Exercises for the Promotion of Employees in selected Public and Private Organisations

(Frequency of Responses of Respondents) (\%)

\begin{tabular}{|c|c|c|c|c|c|c|}
\hline & \multicolumn{3}{|c|}{ ORGANISATIONS } & & \\
\hline & \multicolumn{2}{|c|}{ Public } & \multicolumn{2}{c|}{ Private } & \\
\hline Year of Employment & Frequency & $\%$ & Frequency & $\%$ & Frequency & $\%$ \\
\hline Before 1990 & & & & & & \\
\hline $1991-2000$ & 4 & 9.3 & 3 & 5.7 & 7 & 7.3 \\
\hline 2001-2010 & 4 & 9.3 & 1 & 1.9 & 5 & 5.2 \\
\hline 2010 until date of survey & 26 & 20.9 & 3 & 5.7 & 12 & 12.5 \\
\hline Total & 43 & 100.0 & 53 & 100.0 & 96 & 75.0 \\
\hline $\begin{array}{c}\text { Is promotion a regular } \\
\text { practice? }\end{array}$ & Frequency & $\%$ & Frequency & $\%$ & Frequency & $\%$ \\
\hline Yes & 29 & 67.4 & 12 & 22.6 & 41 & 42.7 \\
\hline No & 14 & 32.6 & 41 & 77.4 & 55 & 57.3 \\
\hline Total & 43 & 100.0 & 53 & 100.0 & 96 & 100.0 \\
\hline If not, why? & Frequency & $\mathbf{\%}$ & Frequency & $\%$ & Frequency & $\%$ \\
\hline $\begin{array}{c}\text { Depends on available } \\
\text { positions }\end{array}$ & 12 & 85.7 & 33 & 80.5 & 47 & 85.5 \\
\hline Depends on the need for it & 2 & 14.3 & 8 & 19.5 & 8 & 14.5 \\
\hline Total & 14 & 100.0 & 41 & 100.0 & 55 & 100.0 \\
\hline $\begin{array}{c}\text { How do employees get } \\
\text { promoted? }\end{array}$ & Frequency & $\%$ & Frequency & $\%$ & Frequency & $\%$ \\
\hline $\begin{array}{c}\text { When management feels } \\
\text { like it }\end{array}$ & 1 & 2.3 & 17 & 32.1 & 18 & 18.8 \\
\hline After a stipulated period & 28 & 65.1 & 33 & 62.3 & 61 & 63.5 \\
\hline Others & 14 & 32.6 & 3 & 5.7 & 17 & 17.7 \\
\hline Total & 43 & 100.0 & 53 & 100.0 & 96 & 100.0 \\
\hline
\end{tabular}

Respondents were further requested to explain the procedures for promotion within their work places. Employees of both public and private organizations (65.1 percent and 62.3 percent) claimed that promotion takes place after a stipulated period. However, 2.3 (32.1) percent of employees in public/private organizations claimed that promotion only takes place when the management feels like it. It appears that private organizations mainly follow this practice; IDI shed further light on this:

Promotion is a function of so many factors; you may have spent the statutory years, and the management may decide that you are not going be promoted even when you have not committed any offence. I have a friend who has been at a particular 
grade for five years without being promoted. The reason the management gave was that the organization simply didn't have the financial capacity to do that [make a promotion] (Female, IDI, Private establishment, Ado Ekiti).

These findings are not unusual: studies have confirmed that career advancement is a product of many factors which can be subsumed under the categories 'objective' and 'subjective'; objective factors include those factors that can be categorised as human-capital related (experience, education, continuous work history, and tenure), demographic (gender and marital status), interpersonal processes and organisational (mentoring) (Whitely et al. 1991; Whitely - Coetsier 1993). Subjective factors may not be directly observable, yet they are correlated to perceptions about the above issues and how they relate to career satisfaction and job satisfaction. In most instances, these are the issues generally considered by management when deciding on promotions. Workers equally have their own perceptions about what deserves or determines promotion, and in most instances such perceptions dominate those of the organisations, especially when the former are unable to meet the requirements of the organisation for career advancement.

Table 4: Number of times respondents have been promoted, and whether procedures for promotion are specified in selected Public and Private Organisations (Frequency of Responses of Respondents) (\%)

\begin{tabular}{|c|c|c|c|c|c|c|}
\hline \multirow[b]{3}{*}{$\begin{array}{l}\text { Do well-defined criteria } \\
\text { for promotion exist? }\end{array}$} & \multicolumn{4}{|c|}{ ORGANISATIONS } & \multirow[b]{3}{*}{ Frequency } & \multirow[b]{3}{*}{$\%$} \\
\hline & \multicolumn{2}{|c|}{ Public } & \multicolumn{2}{|c|}{$\begin{array}{r}\text { Private } \\
\end{array}$} & & \\
\hline & Frequency & $\%$ & Frequency & $\%$ & & \\
\hline Yes & 42 & 97.7 & 38 & 71.7 & 80 & 83.3 \\
\hline No & 1 & 23.0 & 15 & 29.3 & 16 & 16.7 \\
\hline Total & 43 & 100.0 & 53 & 100.0 & 96 & 100.0 \\
\hline No of times promoted & Frequency & $\%$ & Frequency & $\%$ & Frequency & $\%$ \\
\hline 1 & 6 & 14.0 & & & 19 & 19.8 \\
\hline 2 & 21 & 48.8 & 13 & 24.5 & 59 & 61.5 \\
\hline 3 & 3 & 7.0 & 38 & 71.7 & 4 & 4.2 \\
\hline 4 & 4 & 9.3 & 1 & 1.9 & 4 & 4.2 \\
\hline 5 & 4 & 9.3 & & & 4 & 4.2 \\
\hline 6 & 3 & 7.0 & & & 3 & 3.1 \\
\hline 7 & 1 & 2.3 & & & 1 & 2.1 \\
\hline 8 & 1 & 2.3 & 1 & 1.9 & 1 & 1.0 \\
\hline 9 & 1 & 2.3 & & & 1 & 1.0 \\
\hline Total & 43 & 100 & 53 & 100.0 & 96 & 100.0 \\
\hline
\end{tabular}


Table 4 illustrates the existence of criteria for promotion for respondents within their work places. A majority ( 97.7 percent public, and 71.7 percent private establishment) of respondents confirm the existence of defined processes. IDI further support this:

For you to be promoted at the workplace, you must have spent a minimum of three years at that level, and must have been assessed by your immediate boss to behave well and be fit for promotion. Once this is done, there is usually a management meeting where a decision is made regarding whether you are qualified for promotion (Male, IDI, Public establishment, Ado Ekiti).

Respondents were asked to list the number of times they had been promoted within their work places. The majority of respondents in public organisations (48.8 percent) claimed they had been promoted two (2) times. A majority of respondents in private organisations (71.7 percent) also claimed that they had been promoted two times since they had joined their organisation. From the Table 4 above it can be seen that respondents enjoyed promotion commensurate with the number of years they had put into their jobs. Interestingly, respondents are well aware of the rules that determine promotion within their workplaces. This may of course be responsible for the advancement they have enjoyed in their careers.

However, respondents from private establishments seem not to have enjoyed the kind of promotion enjoyed by their colleagues in public establishments. According to Spilerman and Peterson (1999), the focus of related research over the years has been the nature of the barriers to movement; i.e. on earning income, rather than on what really constitutes career advancement within the organisation. Investigation of the internal structural arrangements of a firm, with its attendant implications for individual career advancement, is a difficult and emerging topic of research. Moreover, obtaining the necessary information regarding organisational structure and the work history of employees can be difficult, positing further challenges to researchers (Spilerman - Peterson 1999).

Table 5 presents responses to the question whether gender has any relationship with promotion. Findings suggest that there is no relationship between gender and workplace promotion in public organisations ( 90.7 percent of all respondents said that gender does not affect promotion). However, the situation is different in private establishments, where 62.3 percent of respondents claimed that gender does affect promotion within their workplace. Respondents were further asked to describe which of the genders has better prospects of promotion. 17.0 (26.3) percent claimed that males are more likely to be suitably promoted than females, while 14.0 (17.0) percent opined that females are more often promoted than 
Table 5: Does gender have anything to do with promotion in selected Public and Private Organisations?

(Frequency of Responses of Respondents) (\%)

\begin{tabular}{|c|c|c|c|c|c|c|}
\hline & \multicolumn{3}{|c|}{ ORGANISATIONS } & & \\
\hline & \multicolumn{2}{|c|}{ Public } & \multicolumn{2}{c|}{ Private } & & \\
\hline $\begin{array}{c}\text { Do you think your gender } \\
\text { affects your promotion }\end{array}$ & Frequency & $\%$ & Frequency & $\%$ & Frequency & $\%$ \\
\hline Yes & 4 & 9.3 & 33 & 62.3 & 37.59 & 38.5 \\
\hline No & 39 & 90.7 & 20 & 37.7 & & 61.5 \\
\hline Total & 43 & 100.0 & 53 & 100.0 & 96 & 100.0 \\
\hline $\begin{array}{c}\text { Which of the genders has } \\
\text { better experience with } \\
\text { promotion? }\end{array}$ & Frequency & $\mathbf{\%}$ & Frequency & $\mathbf{\%}$ & Frequency & $\mathbf{\%}$ \\
\hline Male & 7 & 17.0 & 15 & 26.3 & 22 & 23.0 \\
\hline Female & 6 & 14.0 & 9 & 17.0 & 15 & 15.8 \\
\hline Not sure & 30 & 69.0 & 29 & 54.7 & 59 & 61.5 \\
\hline Total & 43 & 100.0 & 53 & 100.0 & 96 & 100.0 \\
\hline $\begin{array}{c}\text { Do you think there is } \\
\text { equality in promotion } \\
\text { between genders? }\end{array}$ & Frequency & $\%$ & Frequency & $\%$ & Frequency & $\%$ \\
\hline Yes & 18 & 41.9 & 28 & 52.8 & 46 & 47.9 \\
\hline No & 25 & 58.1 & 25 & 47.2 & 50 & 52.1 \\
\hline Total & 43 & 100.0 & 53 & 100.0 & 96 & 100.0 \\
\hline
\end{tabular}

males in public and private organisations (resp.). However, 69.0 (54.7) percent of respondents from public and private organisations (resp.) claimed they were not sure which of the genders had better experiences with promotion.

This finding contradicts what was initially claimed by respondents regarding whether gender disparity exists regarding promotion. It appears that the majority of respondents were not willing to provide a categorical response to the question which of the genders gets promoted more, and the number of 'not sure' responses given by respondents clearly attests to this fact. The IDI session, however, throws some light on the perceptions of respondents regarding the trend of career advancement of respondents in relation to gender:

Of course, we all know that when it comes to men and women accessing opportunities, women always have a better chance than men, and the same scenario may be applicable to the work situation but that doesn't mean that women are not hardworking or that they cut corners to get promoted within the work environment (Female, IDI, Public establishment, Ado Ekiti). 
Respondents were asked whether they think gender equality exists regarding promotion within their work setting. Responses revealed that 41.9 (52.8) percent in public and private organisations were of the opinion that it does exist. However, 58.1 (47.2) percent of respondents in public and private establishments (resp.) submitted that it does not exist. From the table it can be seen that a little more than half of all respondents felt that there was gender disparity in promotion. The IDI session helped clarify the situation:

There is disparity in promotion between males and females in any organisation. Women always know how to corner men, they always get what they want at any time; they always know someone that knows the people who decide about promotions (Male, IDI, Public establishment, Ado Ekiti).

Respondents believed that gender affects career advancement. Some studies have confirmed this position, arguing that career advancement differs according to gender status (Bateson 1990; Gallos 1989), although others have argued that gender and career progress are not correlated (O'Neil et al. 2008). There has evidently been a lot of improvement regarding gender differences and career advancement. Studies show that gender may not be an impediment to career advancement, a more significant effect being played by other factors such as education (Peter - Horn 2005). However, considering the present study, while the statistical evidence may not support the presence of a link between gender and career advancement, interview reports clearly suggest otherwise. The perception of respondents is that the issue of gender affects career advancement at certain times. Quite a number of respondents were still of the opinion that gender differences still determine career advancement.

This section examines the factors that enhance occupational mobility and how it affects respondents at the workplace. To start with, respondents were asked whether there are factors that enhance mobility in productivity at their work place; in their responses, 86.0 (81.1) percent of respondents in public and private establishments affirmed this, while 14.0 (18.9) percent of respondents (public and private establishments, resp.) disagreed. Following up on this question, respondents were also requested to identify the factors that they felt enhanced productivity at their work place; 9.3 (52.8) percent of respondents in public and private organisations attributed this to training, while 90.7 (47.2) percent in public and private organisations (resp.) ascribed this to leave and holidays.

Respondents were further asked whether these factors were consistent within their work places. A majority of respondents (86.7/ 73.6 percent) in public and private organisations responded positively. Respondents were further asked 
whether these factors were binding for both males and females. Their responses were affirmative, as 90.7 (92.5) percent of respondents in public and private establishments (resp.) agreed. Some of the responses obtained from the IDI session are that represent the arguments of the respondents included below:

We go on our annual leave when this is due...both males and females have access to this at any time they like, but it's not everybody that has the opportunity to go for training (IDI, Male, Public Organisation).

Table 6: Factors enhancing career mobility in selected Public and Private Organisations (Frequency of Responses of Respondents) (\%)

\begin{tabular}{|c|c|c|c|c|c|c|}
\hline \multirow[b]{3}{*}{$\begin{array}{c}\text { Are there factors that } \\
\text { enhance productivity at } \\
\text { your workplace? }\end{array}$} & \multicolumn{4}{|c|}{ ORGANISATIONS } & \multirow[b]{3}{*}{ Frequency } & \multirow[b]{3}{*}{$\%$} \\
\hline & \multicolumn{2}{|c|}{ Public } & \multicolumn{2}{|c|}{ Private } & & \\
\hline & Frequency & $\%$ & Frequency & $\%$ & & \\
\hline Yes & 27 & 86.0 & 43 & 81.1 & 80 & 83.3 \\
\hline No & 6 & 14.0 & 10 & 18.9 & 16 & 16.7 \\
\hline Total & 43 & 100.0 & 53 & 100.0 & 96 & 100.0 \\
\hline What are they? & Frequency & $\%$ & Frequency & $\%$ & Frequency & $\%$ \\
\hline Training & 4 & 9.3 & 28 & 52.8 & 32 & 33.3 \\
\hline Leave/holiday & 39 & 90.7 & 25 & 47.2 & 64 & 66.7 \\
\hline Total & 43 & 100.0 & 53 & 100.0 & 96 & 100.0 \\
\hline $\begin{array}{l}\text { Are these factors } \\
\text { consistent? }\end{array}$ & Frequency & $\%$ & Frequency & $\%$ & Frequency & $\%$ \\
\hline Yes & 36 & 83.7 & 39 & 73.6 & 75 & 78.1 \\
\hline No & 7 & 16.3 & 14 & 26.4 & 21 & 21.9 \\
\hline Total & 43 & 100.0 & 53 & 100.0 & 96 & 100.0 \\
\hline $\begin{array}{l}\text { Are these factors binding } \\
\text { for both genders? }\end{array}$ & Frequency & $\%$ & Frequency & $\%$ & Frequency & $\%$ \\
\hline Yes & 39 & 90.7 & 49 & 92.5 & 88 & 91.7 \\
\hline No & 4 & 9.3 & 4 & 7.5 & 8 & 8.3 \\
\hline Total & 43 & 100.0 & 53 & 100.0 & 96 & 100.0 \\
\hline $\begin{array}{l}\text { What are the criteria for } \\
\text { promotion? }\end{array}$ & Frequency & $\%$ & Frequency & $\%$ & Frequency & $\%$ \\
\hline Educational qualifications & 7 & 16.3 & 4 & 7.5 & 11 & 11.5 \\
\hline $\begin{array}{l}\text { Years of experience } \\
\text { Connections }\end{array}$ & $\begin{array}{c}25 \\
2\end{array}$ & $\begin{array}{c}58.1 \\
4.6\end{array}$ & $\begin{array}{l}26 \\
15\end{array}$ & $\begin{array}{l}19.1 \\
28.5\end{array}$ & $\begin{array}{l}51 \\
17\end{array}$ & $\begin{array}{l}53.1 \\
17.7\end{array}$ \\
\hline Availability of position & 9 & 20.9 & 8 & 15.1 & 17 & 17.7 \\
\hline Total & 43 & 100.0 & 53 & 100.0 & 96 & 100.0 \\
\hline
\end{tabular}


Further, respondents were asked to describe the criteria for promotion at their workplaces; 16.3 (7.5) percent attributed it to educational qualifications/ attainment; 58.1 (19.1) percent to years of experience; 4.6 (28.5) percent to connections (i.e. who you know at management level to fast track your promotion) while the rest (20.9/15.1 percent) attributed it to the availability of positions within the work settings (all findings correspond to public/private establishments, respectively). IDI, however, identified some contrasting comments, some of which follow:

Promotion is a function of management interest. If you are not giving them what they want in terms of productivity, certificates, years of experience and all the formal issues may not count (IDI, Male, Private Organisation).

Another respondent:

Experience and hard work matters when it comes to promotion, but you need to know people where it matters that can assist you ... (IDI, Male, Public Organisation).

To explain the determinants of career advancement within the workplace, each organisation usually defines patterns or requirements for promoting its staff and for achieving its aims. These are typically understood and in line with employees' goals. Studies emphasise the importance of creating synergy between employees' personal goals and organisational ones (Sturges et al. 2001). However, from the study it appears this may not occur in reality: respondents clearly have their own goals and perceptions which, in the long run, enable them to form opinions about what constitute criteria for promotion at their workplace.

Table 7: Hindrances to career advancement in selected Public and Private Organisations (Frequency of Responses of Respondents) (\%)

\begin{tabular}{|c|c|c|c|c|c|c|}
\hline \multirow[b]{3}{*}{ Barriers to staff promotion } & \multicolumn{4}{|c|}{ ORGANISATIONS } & \multirow[b]{3}{*}{ Frequency } & \multirow[b]{3}{*}{$\%$} \\
\hline & \multicolumn{2}{|c|}{ Public } & \multicolumn{2}{|c|}{ Private } & & \\
\hline & Frequency & $\%$ & Frequency & $\%$ & & \\
\hline Transfers & 36 & 83.7 & 46 & 86.8 & 82 & 85.4 \\
\hline Laziness & 1 & 2.3 & 1 & 2.3 & 2 & 2.1 \\
\hline Incompetence & 1 & 2.3 & 3 & 5.6 & 4 & 4.2 \\
\hline Appraisals & 2 & 4.7 & 1 & 2.3 & 3 & 3.1 \\
\hline Productivity Issues & 1 & 2.3 & 1 & 2.3 & 2 & 2.1 \\
\hline Absenteeism & 2 & 4.7 & 1 & 2.3 & 3 & 3.1 \\
\hline Total & 43 & 100.0 & 53 & 100.0 & 96 & 100.0 \\
\hline
\end{tabular}




\begin{tabular}{|c|c|c|c|c|c|c|}
\hline $\begin{array}{c}\text { Are there other considerations } \\
\text { for promotion, apart from the } \\
\text { established benchmarks? }\end{array}$ & Frequency & $\mathbf{\%}$ & Frequency & $\mathbf{\%}$ & Frequency & $\%$ \\
\hline Yes & 35 & 81.4 & 28 & 52.8 & 63 & 65.6 \\
\hline No & 8 & 18.6 & 25 & 47.2 & 33 & 34.4 \\
\hline Total & 43 & 100.0 & 53 & 100.0 & 96 & 100.0 \\
\hline What are they? & Frequency & $\mathbf{\%}$ & Frequency & $\mathbf{\%}$ & Frequency & $\%$ \\
\hline Economic situation & 25 & 58.1 & 17 & 32.1 & 42 & 43.8 \\
\hline Management interest & 18 & 41.9 & 36 & 67.9 & 54 & 56.2 \\
\hline Total & 43 & 100.0 & 53 & 100.0 & 96 & 100.0 \\
\hline $\begin{array}{c}\text { Who often benefits from these } \\
\text { other considerations? }\end{array}$ & Frequency & $\mathbf{\%}$ & Frequency & $\mathbf{\%}$ & Frequency & $\%$ \\
\hline Male & 23 & 53.5 & 25 & 47.2 & 48 & 50.0 \\
\hline Female & 20 & 46.5 & 28 & 52.8 & 48 & 50.0 \\
\hline Total & 43 & 100.0 & 53 & 100.0 & 96 & 100.0 \\
\hline
\end{tabular}

The table above examines the hindrances to career advancement as perceived by respondents. Respondents were asked to highlight the barriers to staff promotion. A majority of respondents (83.7/86.8 percent) in public and private establishments (resp.) specified transfers. This may be considered unusual as transfers may not have much to do with promotion. However, during the indepth interviews, respondents shed light on this idea by arguing that, in most cases, promotions are often accompanied by transfers, and employees are not willing to move, then there is no promotion. Further, respondents were asked to explain whether there are other considerations that their organisation takes into account in making promotions, apart from those documented, or those used as benchmarks. 81.4 (52.8) percent of respondents in public and private establishments claimed that such criteria exist. Following this, respondents were asked to describe such criteria. 58.1 (32.1) percent of public and private establishment respondents (resp.) attributed it to the prevailing economic situation, while 41.9 (67.9) percent attributed it to management interests. IDI shed more light on some of these responses:

Management often acts in a way that is not black and white regarding promotion - if they claim they don't have enough funds to handle promotion there is nothing anyone can do; one would rather be careful so that one is not laid off: half a loaf of bread, as they say, is better than none (IDI, Male Public Organisation, Ado Ekiti).

Further, respondents were also asked about which gender benefits more from other criteria that are not documented; 53.5 (47.2) percent of respondents in public and private establishments claimed that males benefit more, while 46.5 
(52.8) percent of respondents in public and private organisations (resp.) argue that females tend to benefit more.

Newman (1993) submits that, within organisations, career advancement may be limited by the following factors; human capital (deficient education, domestic restrictions, inadequate financial resources and deficient experience), socio-psychological (social psychological obstacles including sex-role labels/ role prejudice, undesirable perceptions about women's capability for managing, doubtful motivation, and limiting self-concepts) and systemic barriers (isolation of sexes in the labour force, discrepancy in career ladder opportunities, sexbased segregation of domestic labour, limited access to professional training, restricted access to informal networks, lack of advisors, lack of power, sexual harassment, perceived lack of compatibility, and a lack of female role models).

The beliefs and attitudes of members of the workplace have always been considered to have the greatest impact (Cooper Jackson 2001). Workers form views and perceptions about the workplace and are of the opinion that organisations operate using procedures for making promotions which are not clear to them, coupled with a perception that the opposite sex is a hindrance in this regard. Interestingly, most studies have tended to emphasise male-female differences (particularly the claim that females are short-changed by males) as the major hindrance to career advancement, with less emphasis on the beliefs and values held by members of the organisation. Our research suggests that males also believe that women hinder them from advancing in their careers.

Table 8: Gender and career advancement in selected Public and Private Organisations (Frequency of Responses of Respondents) (\%)

\begin{tabular}{|c|c|c|c|c|c|c|}
\hline \multirow[b]{3}{*}{$\begin{array}{c}\text { Do women experience } \\
\text { challenges with promotion? }\end{array}$} & \multicolumn{4}{|c|}{ ORGANISATIONS } & \multirow[b]{3}{*}{ Frequency } & \multirow[b]{3}{*}{$\%$} \\
\hline & \multicolumn{2}{|c|}{ Public } & \multicolumn{2}{|l|}{ Private } & & \\
\hline & Frequency & $\%$ & Frequency & $\%$ & & \\
\hline Yes & 13 & 30.3 & 26 & 49.1 & 39 & \\
\hline No & 9 & 20.9 & 18 & 34.0 & 27 & \\
\hline Sometimes & 21 & 48.8 & 9 & 16.9 & 30 & \\
\hline Total & 43 & 100.0 & 53 & 100.0 & 96 & \\
\hline $\begin{array}{l}\text { Are there issues that hinder } \\
\text { women from being promoted? }\end{array}$ & Frequency & $\%$ & Frequency & $\%$ & Frequency & $\%$ \\
\hline Unwillingness to be transferred & 5 & 11.6 & 19 & 35.8 & 24 & 25.0 \\
\hline Motherhood and childbearing & 6 & 14.0 & 4 & 7.5 & 10 & 10.4 \\
\hline Education & 25 & 58.1 & 22 & 41.5 & 47 & 49.0 \\
\hline Unforeseen family problems & 7 & 16.3 & 8 & 15.1 & 15 & 15.6 \\
\hline Total & 43 & 100.0 & 53 & 100.0 & 96 & 100.0 \\
\hline
\end{tabular}


The table above illustrates how gender differences constrain the career advancement of respondents. Respondents were asked whether women generally experience any form of challenges when it comes to the issue of promotion; 30.3 (49.1) percent of respondents in public and private establishments (resp.) said 'yes', while 20.9 (34.0) percent of employees of public and private establishments said 'no'. However, 48.8 (16.9) percent of respondents from public and private organisations claimed that women sometimes experience some challenges with promotion. IDI responses from two respondents are summarised below:

Promotions have nothing to do with gender. The reason is that there are benchmarks that are measurable and must be achieved before promotion can take place, so it is not an issue of an individual being male or female (IDI, Male, Public Organisation).

Another respondent:

I agree that women may be at a disadvantage when it comes to promotion, and this is because of factors such as family, motherhood, and children, but I believe it is up to the woman to organise herself (IDI, female, Private Organisation).

As a follow up to the questions above, respondents were asked to describe activities that they think could hinder the promotion of women within the workplace. From the table above it can be seen that 11.6 (35.6) percent of respondents within the public and private establishments attributed this situation to the unwillingness of women to be transferred when asked to; 14.0 (7.5) percent in public and private establishments attributed it to motherhood and childbearing; 58.1 (41.5) percent attributed it to education and training issues, while the rest (16.3/15.1 percent, resp.) attribute it to unforeseen family issues. The IDI session further corroborated this data. Some of the respondents' responses are summarised below:

Even after marriage, it is still easier for a man to afford to further his education. By implication, a man will have time to obtain a professional certificate or such a thing at any age, but it may not be entirely possible for a woman to do this. This may be because of pregnancy, or childbirth, or the demands of the workplace; these phenomena increase her responsibilities greatly; that is, she is more likely to be burdened with family matters than a man (IDI, female, Private Organisation). 
As discussed earlier, workers within every organisation are guided by their perceptions and beliefs. According to the above findings, women still believe that they are short-changed in terms of their access to benefits within the workplace based on the roles associated with their gender.

Table 9: How to improve the career advancement of employees in selected Public and Private Organisations

\begin{tabular}{|c|c|c|c|c|c|c|}
\hline $\begin{array}{c}\text { (Frequency of Responses of } \\
\text { Respondents) (\%) }\end{array}$ & \multicolumn{5}{|c|}{ Organisations } & \\
\hline $\begin{array}{c}\text { How can employees' career } \\
\text { prospects be enhanced? }\end{array}$ & \multicolumn{2}{|c|}{ Public } & \multicolumn{2}{c|}{ Private } & & \\
\hline $\begin{array}{c}\text { Prompt payment of salaries and } \\
\text { benefits }\end{array}$ & 16 & 37.2 & 17 & 32.1 & 33 & 34.4 \\
\hline Regular training & 7 & 16.3 & 6 & 11.3 & 13 & 13.5 \\
\hline Regular promotions & 20 & 46.5 & 30 & 56.6 & 50 & 52.1 \\
\hline Total & 43 & 100.0 & 53 & 100.0 & 96 & 100.0 \\
\hline $\begin{array}{c}\text { How can gender disparity } \\
\text { in workplace promotions be } \\
\text { reduced }\end{array}$ & Frequency & $\%$ & Frequency & $\%$ & Frequency & $\%$ \\
\hline $\begin{array}{c}\text { Increase education for women } \\
\text { Increase equal opportunities } \\
\text { at workplace }\end{array}$ & 10 & 23.2 & 10 & 18.9 & 20 & 20.8 \\
\hline $\begin{array}{c}\text { Total } \\
\text { More dedication to women }\end{array}$ & 20 & 46.5 & 26 & 49.1 & 46 & 48.0 \\
$\begin{array}{c}\text { More government policies } \\
\text { Management policies }\end{array}$ & 7 & 16.3 & 1 & 1.9 & 8 & 8.3 \\
\hline
\end{tabular}

Respondents were asked to explain how employees' careers can be further enhanced within the workplace. In response, 37.2 (32.2) percent of respondents within the public and private organisations (resp.) submitted that there should be prompt payment of their salaries and benefits. Further, 16.3 (11.3) percent of respondents from public and private establishments believed that their careers could be further enhanced through regular training and workshops, while 46.5 (56.6) percent believed that their careers could advance through being promoted when this is due at the workplace. Some of the responses given by respondents during the IDI session are included below to corroborate these submissions. 
I think that management should endeavour to promote when it is due; the result would be more money and prestige, and one would be able to fulfil one's career dreams before retirement (IDI, Male, Private establishment, Ado Ekiti)

Further, respondents were requested to suggest ways in which disparity in gender promotion could be addressed. 23.2 (18.9) percent (public/private, resp.) emphasized the need to increase education for women; 46.5 (49.1) percent stated a preference for increasing equal opportunities for all in the workplace; 4.7 (5.7) percent specified more dedication by women; 16.3 (1.9) percent emphasised the importance of government policies, while 9.3 (24.5) percent argued that management policies must be better targeted. IDI sessions corroborated these findings; some responses are detailed below:

A big change would occur if men within the management circle changed the way they saw women in general; they need to see them as equals and not as subordinates, and of course judge individuals by what they can do, not by what they feel or think (IDI, female, private establishment, Ado Ekiti).

This statement is of course the expression of the values and beliefs of an employee and, as earlier argued, organisational goals should always support individual needs in the organisation, for it is in such cases that both parties can achieve their goals and objectives.

\section{TESTING OF HYPOTHESES}

The hypotheses formulated for this study are stated and discussed below in alternative forms.

\section{Chi-square Test of Association}

The first hypothesis claims that a significant relationship exists between gender and career advancement. With a Chi-square of 3.841, it appears that a significant relationship between the variables does not exist. What this finding suggests is that the gender of respondents may not have much to do with career advancement, as respondents claim. This finding contrasts with the IDI reports, 
as respondents were of the opinion that women stand to benefit more at the workplace than men when it comes to career advancement. This finding is further correlated with the earlier arguments. There are different perspectives regarding gender differences and career advancement. What becomes clear is that individuals within the workplace hold different values and opinions which shape their attitudes towards goal achievement (e.g. career advancement).

\section{Table 10: Chi-square Test of Association}

\begin{tabular}{|c|c|c|c|}
\hline \multirow[t]{2}{*}{$\begin{array}{c}\text { Factors responsible for } \\
\text { promotion in the workplace }\end{array}$} & \multicolumn{2}{|c|}{ Gender } & \multirow[b]{2}{*}{ Total } \\
\hline & Male & Female & \\
\hline Educational qualifications & 4 & 7 & 11 \\
\hline Years of experience & 5 & 12 & 17 \\
\hline $\begin{array}{l}\text { Qualification plus level of } \\
\text { experience }\end{array}$ & 19 & 32 & 51 \\
\hline Influence/connections & 12 & 0 & 12 \\
\hline Dedication to work & 2 & 3 & 5 \\
\hline Total & 42 & 54 & 96 \\
\hline \multicolumn{3}{|c|}{ Chi-square $=3.841, \mathbf{d f}=\mathbf{4}, \mathbf{p}=. \mathbf{0 0 0}$} & \\
\hline \multirow[t]{2}{*}{ Educational Qualifications } & \multicolumn{2}{|c|}{ Do promotions regularly happen at your workplace? } & \\
\hline & Yes & No & Total \\
\hline Diploma & 3 & 7 & 10 \\
\hline HND & 3 & 7 & 10 \\
\hline B.Sc. & 20 & 26 & 46 \\
\hline M.Sc. & 5 & 3 & 8 \\
\hline Dedication & 9 & 8 & 17 \\
\hline Other Certificates & 2 & 3 & 5 \\
\hline Total & 42 & 54 & 96 \\
\hline \multicolumn{3}{|c|}{ Chi-square $=11.070, d f=5, p=.000$} & \\
\hline
\end{tabular}

The second hypothesis posits that a statistical significant relationship exists between educational qualifications and the career advancement of workers However, findings (11.070) show that there may not be a significant relationship between the variables. In other words, education alone may not be a strong determinant of career advancement. This finding, however, does not agree with the conclusions of earlier studies that claim that education has a considerable effect on career advancement. A number of factors can bring about career advancement, including organisational goals that extend beyond education. 


\section{CONCLUSION}

Career advancement in the selected public and private organisations may not measure up to the expectations of respondents. This is frustrating; the respondents were of the opinion that management devises procedures for promoting their workers which are not known to them. Further, what constitutes career advancement to respondents in private organisations is seen a bit differently by those in the public sector. Respondents in public organisations emphasised training more strongly. However, respondents also believed that career advancement involved regular payment of their salaries and benefits, and prompt promotion to the next level when due.

\section{REFERENCES}

Arthur, Michael B. - Douglas T. Hall - Barbara S. Lawrence (1989), "Generating New Directions in Career Theory: The Case for a Transdisciplinary Approach", in: Arthur, M.B. - Douglas T. Hall - Barbara S. eds., Handbook of Career Theory, Cambridge, Cambridge University Press, pp. 7-25.

Bell, David - David Blanchflower (2011), "Young People and the Great Recession", IZA Working Paper No. 5674.

Barone, Carlo - Mario Lucchini - Antonio Schizzerotto (2011), "Career mobility in Italy"e, European Societies Vol. 13, No 3, pp. 377-400. DOI: 10.1080/14616696.2011.568254

Bateson, Mary Catherine (1990), Composing a Life, New York, Plume Books Blair-Loy, Mary (1999), "Career Patterns of Executive Women in Finance", American Journal of Sociology, Vol. 104, No 5, pp. 1346-1397. DOI: $10.1086 / 210177$

Blau Francine D. - Marianne Ferber - Ann Winkler (2002), The Economics of Women, Men, and Work. The Economics of Women, Men, and Work. $4^{\text {th }}$ Ed. Upper Saddle River, NJ, Prentice Hall

Brüderl, Joseph, - Andreas Diekmann - Peter Preisendorfer (1991), "Patterns of intraorganizational mobility: tournament models, path dependency, and early promotion effects", Social Science Research Vol. 20, No 3, pp. 197-216. https://doi.org/10.1016/0049-089X(91)90005-N

Büttner, Thomas - Peter Jacobebbinghaus - Johannes Ludsteck (2010), "Occupational Upgrading and the Business Cycle in West Germany", Economics: The Open-Access, Open-Assessment E-Journal, 4 (2010-10), pp. 1-37. http://dx.doi.org/10.5018/economics-ejournal.ja.2010-10 
Byrd-Blake, Marie (2004), "Female Perspectives on Career Advancements", Advancing Women in Leadership Journal Vol.15., (online) DOI: https://doi. org/10.18738/awl.v15i0.178

Cahuc, Pierre - Stephanie Carcillo (2011), "Is short-time work a good method to keep unemployment down?” IZA Working Paper No. 5430.

Cooper Jackson, Jenny (2001), "Women middle manager's perception of the glass ceiling", Women in Management Review Vol. 16, No 1, pp. 30-41. https:// doi.org/10.1108/09649420110380265

Dickens, Richard (2000), "Caught in a trap? Wage mobility in Great Britain: 1975-1994”. Economica, Vol. 67, No 268, pp 477-497.

Foster, Sarah-Andrew Purvis (2011), "Career Advancement: A Review of Career Advancement Services and Their Role in Supporting Job Sustainability", Remploy, Leicester

Gallos, Joan (1989), “Exploring Women's Development: Implications For Career Theory, Practice, And Research", in: Arthur, Michael B. - Douglas T. Hall - Barbara S. Lawrence eds., Handbook of Career Theory, Cambridge , Cambridge University Press, pp. 110-132.

Hartmann, Heidi (1979), "The Unhappy Marriage of Marxism and Feminism:Towards a More Progressive Union", Capital and Class Vol. 3, No 2, pp. 1-33

Hall, Douglas (1976), Careers in Organizations. Glenview, Scott Foresman

Kellard, Karen - Leighton Mitchell (2006), "In-Work Support and Job Sustainability: A Brief Review", in Kellard, Francis Mitchell ed., An evaluation of the wise group 'next steps' and one plus 'sustainable employment' projects. Edinburgh, Scottish Executive. http://www.gov.scot/ Resource/Doc/179621/0051063.pdf. Retrieved October 10, 2016.

Newman, Meredith Ann (1993), "Career advancement: does gender make a difference?" The American Review of Public Administration Vol. 24, No 3, pp. 361-385. DOI: 10.1177/027507409302300404

O’Neil, Deborah A. - Margaret M. Hopkins - Diana Bilimoria (2008), "Women's careers at the start of the 21st century: patterns and paradoxes", Journal of Business Ethics Vol. 80, No 4, pp. 727-743. DOI 10.1007/s10551-007-9465-6.

Peter, Katherine - Laura Horn (2005), Gender Differences In Participation And Completion Of Undergraduate Education And How They Have Changed Over Time, Washington, DC, US Dept. of Education

Purcell, John - Nicholas Kinnie - Sue Hutchinson - Bruce Rayton - Juani Swart (2003), Understanding the People and Performance Link: Unlocking the Black Box. London: CIPD http://opus.bath.ac.uk/22252/.

Reinhart, Carmein - Keneth Rogoff (2008), "Banking Crises: An Equal Opportunity Menace", NBER Working Paper No.14587. 
Savage, Adrian (2002), “The Real Glass Ceiling”, http://www.wipcoaching.com/ downloads/the-real-glass-ceiling.pdf Accessed on 20th August, 2015.

Schein, Edgar(1978), Career Dynamics: Matching Individual and Organizational Needs. Reading MA, Addison-Wesley.

Schroeder, Anna - Andrew Miles - Mike Savage - Susan Halford - Gindo Tampubolon (2008), "Mobility, careers and inequalities a study of work-life mobility and the returns from education", Centre for Research on SocioEconomic Change (CRESC), University of Manchester

Spilerman, Seymore - Trond Petersen (1999), "Organizational Structure, Determinants of Promotion, and Gender Differences in Attainment", Social Science Research Vol. 28, No 2, pp. 203-227. https://doi.org/10.1006/ ssre.1998.0644

Stewart, Mark - Joanna Swaffield (1999), "Low Pay Dynamics and Transition Probabilities", Economica, Vol. 66, No 261, pp 23-42. DOI: 10.1111/14680335.00154

Sturges Jane - David Guest - Neil Conway - Kate Mackenzie Davey (2001), "What Difference Does It Make? A Longitudinal Study of the Relationship between Career Management and Organizational Commitment in the Early Years at Work", Academy of Management Proceedings, CAR: B1-B6 DOI: 10.1002/job.164

Tsui, Anne S. - Jone L. Pearce - Lyman W. Porter - Angela M. Tripoli (1997), "Alternative approaches to the employee-organization relationship: does investment in employees pay off?" Academy of Management Journal Vol. 40, No 5, pp. 1089-121. doi: 10.2307/256928

Valcour, P. Monique - Pamela Tolbert (2003), “Gender, Family and Career in the Era of Boundarylessness: Determinants and Effects of Intra-And Inter-Organizational Mobility", International Journal of Human Resource Management Vol. 14, No 5, pp. 768-787. DOI: 10.1080/0958519032000080794 Verick, Sher (2009), "Who is hit hardest during a financial crisis? The vulnerability of young men and women to unemployment in an economic downturn". IZA Discussion Paper No.4359.

Whitely, William - Thomas Dougherty - George Dreher (1991), "Relationship of Career Mentoring and Socioeconomic Origin to Managers' and Professionals' Early Career Progress", Academy of Management Journal Vol. 34, No 2, pp. 331-351.

Whitely, William. T. - Pol Coetsier (1993), “The relationship of career mentoring to early career outcomes", Organization Studies Vo. 14, No 3, pp. 419-441.

Zippel, Kathrin (2000), Sexual harassment and transnational relations: why those concerned with German-American relations should care, Washington, American Institute for Contemporary German Studies, John Hopkins University Accessed January 2015. 
